Cold Spring Harb Perspect Med; doi: 10.1101/cshperspect.a033415

\title{
Retraction: The Evolution and Ecology of Resistance in Cancer Therapy
}

\author{
Robert Gatenby and Joel Brown
}

Cold Spring Harbor Perspectives in Medicine is retracting the above article owing to significant text overlap with an earlier article coauthored by Dr. Gatenby (Enriquez-Navas et al. 2015), which was not cited in the Cold Spring Harbor Perspectives in Medicine paper and for which American Association for Cancer Research (AACR) holds copyright. During the preparation of their manuscript, the authors accidentally submitted the wrong source file, which included duplicated text from the earlier paper, and this incorrect version was carried forward to publication. This retraction is made at the request of the copyright holder. The authors have published a new paper (Gatenby and Brown 2020) to address the issues raised.

\footnotetext{
REFERENCES

Enriquez-Navas PM, Wojtkowiak JW, Gatenby RA. 2015. Application of evolutionary principles to cancer therapy. Cancer Res 75: 4675-4680.

Gatenby RA, Brown JS. 2020. The evolution and ecology of resistance in cancer therapy. Cold Spring Harb Perspect Med doi:10 $.1101 /$ cshperspect.a040972
}

Copyright $(02020$ Cold Spring Harbor Laboratory Press; all rights reserved; doi: 10.1101/cshperspect.a040261 Cite this article as Cold Spring Harb Perspect Med 2020;10:a040261 


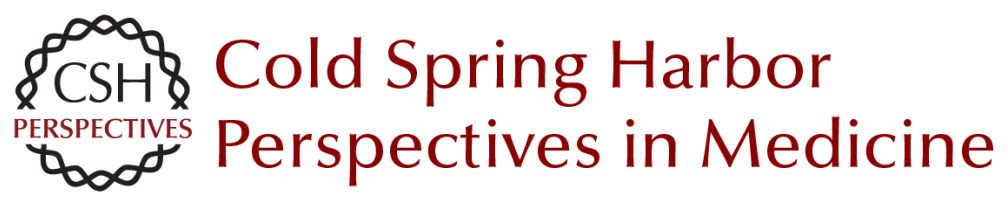

\section{Retraction: The Evolution and Ecology of Resistance in Cancer Therapy}

Robert Gatenby and Joel Brown

Cold Spring Harb Perspect Med 2020; doi: 10.1101/cshperspect.a040261

Subject Collection

For additional articles in this collection, see http://perspectivesinmedicine.cshlp.org/cgi/collection/ 